\title{
Effect of refuge supplement on Audouin's gull chick survival*
}

\author{
JORDI PRIETO ${ }^{1}$, LLUÍS JOVER $^{2}$ and XAVIER RUIZ ${ }^{1}$ \\ ${ }^{1}$ Departament de Biologia Animal, Universitat de Barcelona, Avgda. Diagonal 645, 08028 Barcelona, Spain. \\ E-mail: jprieto@porthos.bio.ub.es \\ ${ }^{2}$ Departament de Salut Pública (Bioestadística), Universitat de Barcelona, Casanova 143, 08036 Barcelona, Spain.
}

\begin{abstract}
SUMMARY: One of the main threats to Audouin's gull (Larus audouinii) at Chafarinas Islands is predation on eggs and chicks by the yellow-legged gull (Larus cachinnans). During the 1999 and 2000 breeding seasons we tested the effects of supplementary refuge availability on chick survival. Well before the laying period, nine adjacent enclosures were erected inside Audouin's gull's breeding grounds and some of them were supplied with artificial refuges. Our results showed significantly greater chick survival in the enclosures with artificial refuges than in control ones. In 2000, an overall lower breeding success of Audouin's gull and a dilution of the refuge effect were observed. These results were probably related to foodshortage that year. We suggest that, along with other factors, an increase in refuge availability may significantly enhance Audouin's gull chick survival.
\end{abstract}

Key words: Larus audouinii, chick survival, refuge supplement, breeding success, western Mediterranean.

RESUMEN: EFectos DEL APORTE DE REFugios SOBRE LA SUPERVIVENCIA DE POLlos DE GAVIOTA DE Audouin. - Una de las principales amenazas de la colonia de Gaviota de Audouin (Larus audouinii) de las islas Chafarinas es la predación sobre huevos y pollos por parte de la gaviota patiamarilla (Larus cachinnans). Durante las temporadas reproductoras de 1999 y 2000 nosotros estudiamos los efectos del aporte artificial de refugios sobre la supervivencia de los pollos. Con anterioridad al inicio del periodo de puesta, se instalaron nueve cercados adyacentes dentro de los límites habituales de la colonia y algunos de ellos fueron dotados con refugios artificiales. Nuestros resultados muestran que la supervivencia de los pollos fue significativamente mayor en los cercados con refugios artificiales en comparación a los cercados control. El año 2000 se observó un éxito reproductor globalmente menor y una dilución del efecto refugio. Estos resultados probablemente guardaron relación con la escasez de alimento aquel año. Se sugiere que, junto con otros factores, un aumento en la disponibilidad de refugios puede aumentar significativamente la supervivencia de los pollos de gaviota de Audouin.

Palabras clave: Larus audouinii, supervivencia de pollos, aporte de refugios, éxito reproductor, Mediterráneo occidental.

\section{INTRODUCTION}

The Chafarinas Islands archipelago holds important colonies of Audouin's (Larus audouinii) and yellow-legged gulls (Larus cachinnans), with 3,320 and 3,370 breeding pairs respectively (Ruiz et al., 2000).

*Received September 23, 2001. Accepted September 8, 2002.
Earlier studies in different colonies have reported a high degree of interaction between the two species (de Juana et al., 1984; Bradley, 1988; Oro and Martínez-Vilalta, 1994). Recent studies at Chafarinas (González-Solís et al., 1997b) showed that when the two species breed syntopically, yellow-legged gulls interfere with Audouin's gull. The most characteristic interactions are predation on eggs and chicks, aerial kleptoparasitism, courtship or chick 
feeding kleptoparasitism, agonistic interactions and possible competition for breeding territories. Moreover, factors like food availability, the relative numbers of both species or the colony size can influence the intensity of these interactions (Witt et al., 1981; de Juana et al., 1984; Varela and de Juana, 1986; Bradley, 1988; Oro and Martínez-Vilalta, 1994; Oro et al., 1996a; Oro et al., 1996b; Ruiz et al., 1996; González-Solís et al., 1997b).

The effects of yellow-legged gull predation on Audouin's gull productivity depend largely on the relative numbers of the two species (Oro et al., 1996a; González-Solís et al., 1997b). This is because yellowlegged gull individuals predating on Audouin's gulls are specialists in the use of this resource and their numbers are proportional to colony size. Therefore, when Audouin's and yellow-legged gulls breed in imbalaced proportions the effects can range from devastating to negligible, depending on which species dominate (Oro et al., 1996b).

At the Chafarinas Islands, the number of pairs of Audouin's gull in the colony has increased steadily since the first census in the 1960s. Despite some annual fluctuations in breeding numbers, the present population seems to be stabilised around 3,300 pairs. The yellow-legged gull population increased rapidly in the early 1980s (5,000 pairs in 1985), and a culling programme (1987-1992) on adults and eggs was carried out to facilitate the recovery of the Audouin's gull local population. During this period, the number of Audouin's gulls rose to 4,000 pairs in 1992 (Álvarez, 1992) and that of yellow-legged gulls dropped to about 1,500 pairs in 1993. However, since then the population of yellow-legged gulls has rapidly recovered to present numbers (about 3,400 pairs), and the ratio between the two species is roughly 1:1.

One of the main factors affecting offspring survival in gulls is the presence of places to hide in the surroundings of the nest (Haymes and Blokpoel, 1978). This is because hides allow better predator avoidance and also minimise thermal stress, thus enhancing chick survival (Parsons, 1982; Parsons and Chao, 1983). At the Chafarinas Islands yellowlegged gulls start to breed one month earlier than Audouin's gulls and in general the territories occupied by the latter are less vegetated (Ruiz et al., 1996); the situation is thus fully suitable for testing the effects of supplementary refuges on Audouin's gull offspring survival and their usefulness as a management tool for conservation purposes in this breeding colony, the second largest in the world (Ruiz et al., 1996).

\section{STUDY AREA AND METHODS}

The field work was carried out in 1999 and 2000 at Chafarinas (Melilla: $\left.35^{\circ} 11^{\prime} \mathrm{N}, 3^{\circ} 46^{\prime} 35^{\prime \prime} \mathrm{E}\right)$ during the Audouin's gull chick-rearing period (June-July). The study was done at Rey Island on which more than $98 \%$ of the Audouin's gulls in the archipelago were breeding during both years.

The north area of the island, which has a poor vegetation cover but holds the largest breeding nucleus (Ruiz et al., 1996, 2000), was chosen for the experiment. There, we selected an area in which to carry out the experiment (enclosure area), and we used the rest of the subcolony as a reference (reference area) to determine whether the enclosure area was homogeneous with the rest of the subcolony. The enclosure area was $15 \times 15 \mathrm{~m}$ in size, and was subdivided into nine $5 \times 5 \mathrm{~m}$ internal enclosures delimited using $0.5 \mathrm{~m}$ high wire netting (Fig 1A). The netting was attached to the ground to prevent the movement of chicks between the different internal enclosures.

The experiment aimed to compare the breeding success of Audouin's gull between two areas within the enclosure: (1) control enclosures and (2) refugesupplemented enclosures, where artificial refuges were installed as a potential protection for chicks.

Artificial refuges were made of wooden boards of $1.20 \times 1.20 \mathrm{~m}$, supported at each end $20 \mathrm{~cm}$ above the ground, thus providing room for chicks to hide. In order to randomise our sample, the experimental area was defined in the field by the end of March, before the start of the laying period. Five and four of the nine $5 \times 5 \mathrm{~m}$ internal enclosures were randomly selected in 1999 and 2000 respectively. In each of these selected enclosures, two artificial refuges were installed by dividing selected enclosures into $251 \mathrm{x}$ $1 \mathrm{~m}$ squares excluding the central and the 16 peripheral $1 \times 1 \mathrm{~m}$ squares and randomly selecting one of the remaining eight to place a supplementary refuge. The second refuge was installed directly opposite the first (Fig. 1B). The refuges were installed before the laying period to avoid the destruction of nests and an excess of disturbance during the incubation, but the netting was not erected until the incubation period. No further human disturbance took place from net placement to ringing of chicks.

In each of the nine enclosures, vegetation cover was estimated using cumulative sub-samples of 1 $\mathrm{m}^{2}$. For each $5 \times 5 \mathrm{~m}$ square we then calculated the percentage of ground covered by plants. In the refuge-supplemented and control enclosures, as well 
A

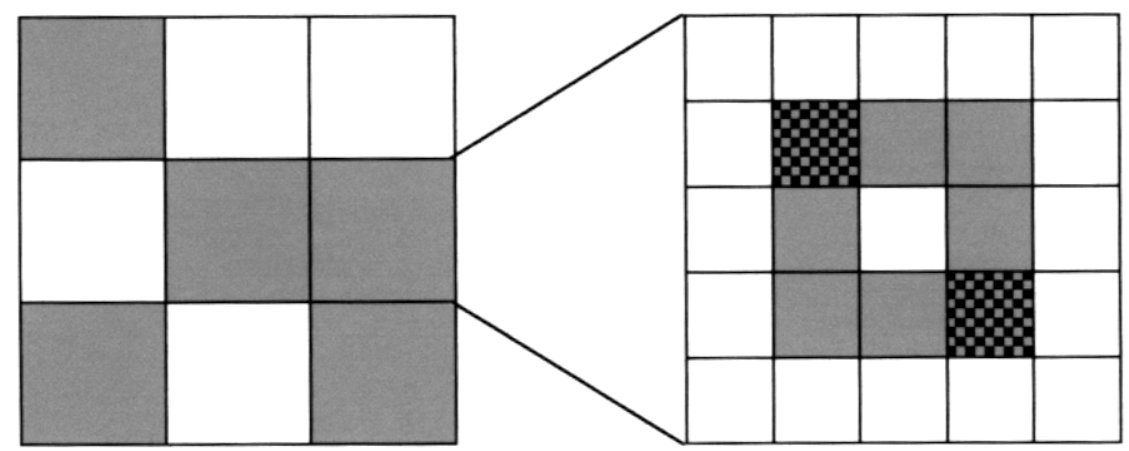

Randomly selected enclosures to contain refuge supplement.

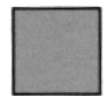

Possible locations for refuges inside the enclosures.

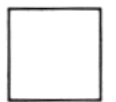

Enclosures with only natural vegetation cover

\section{Randomly placed refuges}

FIG. 1. - Design of enclosure area A (15 x $15 \mathrm{~m})$ and refuge supplemented enclosure B (5 x $5 \mathrm{~m})$.

as in a random sample of nests in the reference area, we recorded mean clutch size and mean egg volume in a clutch, though the latter was only measured for three-egg clutches (i.e. the modal clutch size). To estimate mean egg volume in a clutch, we used a combination of two linear measurements: Egg volume $=0.485 \times$ length $\mathrm{x}$ width $^{2}$ (Ruiz et al., 1996). Breeding success was calculated as an average (i.e. dividing the number of fledglings surviving in every enclosure by the number of nests it contained) and expressed as number of chicks per pair.

Although laying date could be another factor affecting reproductive success (Wendeln, 1997; review in Moreno, 1998), we did not carry out a close surveillance of this factor in order to reduce disturbance to breeding pairs. Nevertheless, previous studies indicated that the main differences in laying date correspond to different subcolonies (Ruiz et al., 1996), so we assumed that breeding pairs within the same subcolony were relatively synchronous.

\section{Statistical methods}

To determine whether the study area was representative of the subcolony, we compared clutch size and mean egg volume between the experimental and the reference area using the Mann-Whitney and ttests respectively.

The Mann-Whitney U statistic was also used to assess differences in vegetation cover and clutch size between the refuge-supplemented and control enclosures, whilst we used the t-test to compare mean egg volumes. The breeding success in the refuge-supplemented and control enclosures was compared using a 2 x 2 contingency table stratified by year. The homogeneity of the strata was evaluated with a Breslow-Day test and the Mantel-Haenszel $\chi^{2}$ statistic was used to test the association between breeding success and presence of artificial refuges.

\section{RESULTS}

\section{Enclosure vs reference area}

We did not detect significant differences in either of the two years for clutch size (Mann-Whitney test, year 1999: $Z=-0.131 ; p=0.896$; year 2000: $Z=-$ $0.942 ; \mathrm{p}=0.346)$ (Table 1) or mean clutch volume $(\mathrm{t}-$ test: Year 1999: $\mathrm{t}=-0.744$; d.f. $=54 ; \mathrm{p}=0.460$; Year 2000: $\mathrm{t}=-0.100 ;$ d.f. $=88 ; \mathrm{p}=0.921)$ (Table 2).

\section{Control vs refuge-supplemented enclosures}

We did not detect significant differences between control and refuge-supplemented enclosures in vegetation cover (Mann-Whitney test: $\mathrm{Z}=-0.891 ; \mathrm{p}=$ 0.373 ; mean vegetation cover $=31.11 \% \pm$ SD 7.41), clutch size (Mann-Whitney test: Year 1999, Z = 0.549; $\mathrm{p}=0.583$; Year 2000, $\mathrm{Z}=-1.805 ; \mathrm{p}=0.071$ ) (Table 1), or mean clutch volume (t-test: Year 1999, 
TABLE 1. - Percentage distribution of Audouin's gull clutch size in the enclosure area (control and refuge-supplemented enclosures) and the reference area in both years of study. CS1 to CS $\geq 4$ refer to clutch sizes from one to four or more eggs respectively.

\begin{tabular}{lrrrrr}
\hline & $n$ & CS1 & CS2 & CS3 & CS $\geq 4$ \\
\hline Year 1999 & & & & & \\
Enclosure area & & & & & \\
$\quad$ - Control area & 66 & 3.0 & 33.3 & 63.7 & 0.0 \\
$\quad$ - Supplem. area & 99 & 5.1 & 26.3 & 68.6 & 0.0 \\
Reference area & 1020 & 5.8 & 26.5 & 67.7 & 0.0 \\
& & & & & \\
Year 2000 & & & & & \\
Enclosure area & & & & & \\
$\quad$ - Control area & 91 & 11.0 & 25.3 & 62.6 & 1.1 \\
$\quad$ - Supplem. area & 80 & 15.0 & 35.0 & 50.0 & 0.0 \\
Reference area & 1493 & 9.4 & 30.9 & 58.6 & 1.1 \\
& & & & & \\
\hline
\end{tabular}

TABLE 2. - Mean egg volume in a clutch of Audouin's gull in the enclosure area (control and refuge-supplemented enclosures) and reference area in both years of study $(\mathrm{SD}=$ standard deviation and IC $95 \%=95 \%$ confidence interval).

\begin{tabular}{lccccc}
\hline & Mean & SD & n & Lower limit & Upper limit \\
& & & & & \\
\hline Year 1999 & & & & & \\
Enclosure area & & & & & 61.45 \\
$\quad$ Control area & 59.08 & 3.92 & 12 & 56.70 & 62.17 \\
$\quad$ Supplem. Area & 60.08 & 3.29 & 13 & 57.99 & \\
Reference area & 60.26 & 3.45 & 31 & 58.99 & \\
& & & & & 59.53 \\
Year 2000 & & & & & 59.95 \\
Enclosure area & & & & 57.83 & \\
$\quad$ Control area & 58.67 & 2.34 & 32 & 57.40 & \\
$\quad$ Supplem. Area & 58.68 & 2.95 & 23 & 57.30 & \\
Reference area & 58.75 & 4.23 & 35 & 57.30 & \\
& & & & & \\
\hline
\end{tabular}

TABLE 3. - Breeding success of Audouin's gull at the enclosure area in the two years of study. Number of nests, eggs, fledglings and breeding success are given for each year in refuge-supplemented and control enclosures.

\begin{tabular}{lcccc}
\hline & $\begin{array}{c}\text { Nests } \\
(\mathrm{n})\end{array}$ & $\begin{array}{c}\text { Eggs } \\
(\mathrm{n})\end{array}$ & $\begin{array}{c}\text { Fledglings } \\
(\mathrm{n})\end{array}$ & $\begin{array}{c}\text { Breeding } \\
\text { success } \\
\text { (chicks/pair) }\end{array}$ \\
& & & & \\
Year 1999 & & & & 0.42 \\
Control area $(\mathrm{n}=4)$ & 66 & 174 & 28 & 0.86 \\
Suppl. Area $(\mathrm{n}=5)$ & 99 & 261 & 85 & \\
Year 2000 & & & & 0.22 \\
Control area $(\mathrm{n}=5)$ & 91 & 231 & 20 & 0.30 \\
Suppl. Area $(\mathrm{n}=4)$ & 80 & 188 & 24 & \\
\hline
\end{tabular}

$\mathrm{t}=0.691 ;$ d.f. $=23 ; \mathrm{p}=0.497 ;$ Year 2000, $\mathrm{t}=0.000$ d.f. $=53 ; \mathrm{p}=1.000)($ Table 2$)$.

In both study years, breeding success (chicks/pair) in the refuge-supplemented enclosures was higher than in the control enclosures, but such differences were much greater in 1999 than in 2000 (Table 3). We did not find significant differences between the strata defined by year and enclosure $\left(\chi^{2}\right.$ $=1.482 ;$ d.f $=1 ; \mathrm{p}=0.224)$. Thus, we performed a general analysis of the relationship between breeding success and refuge availability. There was a positive and statistically significant association between breeding success and presence of supplementary refuges (Mantel-Haenszel: $\chi^{2}=21.906$; d.f. $=1 ; \mathrm{p}<$ $0.0001)$. The stratified odds-ratio statistic of association was 2.384 (IC 95\%=1.646-3.454), indicating that the probability of fledging in enclosures with additional refuges was roughly double that in control enclosures.

\section{DISCUSSION}

Chick survival depends on several factors: parental quality, food availability, clutch size, hatching order, predation rates, diseases and weather conditions (Hébert, 1987; Bolton, 1991; Hario, 1994; Kilpi, 1995; Kilpi et al., 1996; Monaghan et al., 1998). In our study, there were no significant differences in clutch size and mean egg volume between the enclosure and reference areas, indicating that parental quality was similar between them. Similarly, there were no differences for the same parameters and vegetation cover between the control and refuge-supplemented squares within the enclosure zone. We therefore considered the whole enclosure and the reference areas to be fairly similar, from the point of view of both breeders and habitat quality (i.e. vegetation cover) during the laying season. Therefore, the overall significantly higher chick-survival rate in the refuge-supplemented enclosures suggests a direct beneficial effect of such refuges. However, the fact that in 2000 this effect was largely diluted (Table 3 ) also indicates that factors other than predator avoidance or reduction of thermal stress account for chick survival.

Several studies on Audouin's gull and other Mediterranean seabirds have shown a relationship between food availability and fisheries activity near the colonies, which are usually well reflected in some breeding parameters and/or behavioural patterns (Bosch et al., 1994; Castilla and Jiménez, 1995; Oro, 1995; Oro et al., 1995; Oro et al., 1996a; Oro et al., 1996b; Arcos and Oro, 1996; GonzálezSolís et al., 1997a; Oro and Ruiz, 1997; Oro et al., 1997; González-Solís et al., 1999). Although quantitative data on Moroccan fisheries and their catches near the Chafarinas Islands were not available, a lower activity of local fisheries due to bad weather 
conditions and an associated food-shortage period due to scarcity of discards were observed in 2000. This was probably a major factor causing a lower breeding success in that season and diluting the effect of refuges. Moreover, other side-effects of bad weather (e.g. chilling) cannot be ruled out as accounting for the greater mortality in 2000 .

Thus, despite the overall relationship between breeding success and refuge availability, our data show that other factors affected the survival probability of Audouin's gull chicks at the Chafarinas Islands. Food availability is one of the main factors affecting breeding success, although its influence depends on the phase of the breeding period affected. In the Ebro Delta, a site located $800 \mathrm{~km}$ further north, which holds the largest colony of Audouin's gull in the world, clutch size was reduced when the laying period was affected by food scarcity, and productivity fell when the chick rearing period was affected (Oro et al., 1996a).

In our study there were no differences in egg or clutch size between 1999 and 2000, so any food shortage period at Chafarinas would only have affected the chick-rearing period. Low food availability may influence feeding rate, adult attendance, intraspecific kleptoparasitism and predation by yellow-legged gulls. We suggest that at Chafarinas food availability was the main factor affecting Audouin's gull breeding success. However, other factors such as refuge availability, which significantly increases offspring survival by providing protection against predation and overheating, could also be important, particularly in the breeding seasons without the influence of factors like reduced food availability.

Other studies have shown benefits of refuge availability for chicks of terns or gulls (Parsons and Chao, 1983; Burness and Morris, 1992; Recorbet and Bonaccorsi, 1996), but our study is the first to quantify such benefits for the survival of Audouin's gull chicks. The results suggest that artificial refuges might be useful tools for the management and protection of this vulnerable gull species.

\section{ACKNOWLEDGEMENTS}

We thank Isabel Afán for her help during fieldwork, members of GENA for their technical support and logistic help on the islands and our team colleagues at the Universitat de Barcelona, Antonio Hernández, José Manuel Arcos and Jacob GonzálezSolís, for their critical reading and comments.
Research funds were provided by OAPN and the Universitat de Barcelona.

\section{REFERENCES}

Álvarez, G. - 1992. Conservation programme for Audouin's gull in the Chafarinas Islands, Avocetta, 16: 63-66.

Arcos, J.M. and D. Oro. - 1996. Changes in foraging range of Audouin's gull Larus audouinii in relation to a trawler moratorium in western Mediterranean, Colon. Waterbirds, 19: 128-131.

Bolton, M. - 1991. Determinants of chick survival in the Lesser Black-backed gull: relative contributions of egg size and parental quality, J. Anim. Ecol., 60: 949-960.

Bosch, M., D. Oro and X. Ruiz. - 1994. Dependence of yellowlegged gull Larus cachinnans on food from human activity in two western Mediterranean colonies, Avocetta, 18:135-139.

Bradley, P. - 1988. The breeding biology of Audouin's gull at the Chafarinas Islands. In: Medmaravis and X. Monbailliu (eds.), NATO ASI series, vol, 12, pp 221-230. Springer-Verlag, Berlin.

Burness, G.P. and R.D. Morris. - 1992. Shelters decrease gull predation on chicks at a common tern colony, J. Field Ornithol., 63(2): 186-189

Castilla, A.M. and J. Jiménez. - 1995. Relationship between fishery activities and presence of the Audouin's gull (Larus audouinii) in Columbretes Islands, Colon. Waterbirds, 18: 108-112.

de Juana, E., J. Varela and H.H. Witt. - 1984. The conservation of seabirds at the Chafarinas Islands. International Council for Bird Preservation Technical Publication 2: 363-369.

González-Solís, J., D. Oro, L. Jover, X. Ruiz and V. Pedrocchi. 1997a. Trophic niche width and overlap of two sympatric gulls in the south-western Mediterranean, Oecologia, 112: 75-80.

González-Solís, J., X. Ruiz and L. Jover. - 1997b. Influence of food availability on interactions between Larus cachinnans and $L$. audouinii, Can. J. Zool., 75: 719-724.

González-Solís, J., X. Ruiz and L. Jover. - 1999. Fisheries and daily activity cycles of Audouin's Larus audouinii and yellowlegged gulls $L$. cachinnans breeding at the Chafarinas Islands (Moroccan coast), Die Vogelwarte, 40: 52-56.

Hario, M. - 1994. Reproductive performance of the nominate Lesser Black-backed gull under pressure of Herring gull predation, Ornis fennica, 71: 1-10.

Haymes, G.T. and H. Blokpoel. - 1978. Reproductive success of Larids nesting on the eastern headland of the Toronto Outer Harbour in 1997, Ontario Field Biol., 32: 1-17.

Hébert, P.N. - 1987. Effect of fog on Herring gull (Larus argentatus) chick survivorship and parental foraging patterns, Colon. Waterbirds, 10: 103-105.

Kilpi, M. - 1995. Egg size asymmetry within Herring gull clutches predicts fledging success, Colon. Waterbirds, 18: 41-46.

Kilpi, M., L. Hillström and K. Lindström. - 1996. Egg-size and reproductive success in the Herring gull Larus argentatus adaptative or constrained size of the last egg? Ibis, 138: 212-217.

Monaghan, P., R.G. Nager and D.C. Houston. - 1998. The price of eggs: increased investment in egg production reduces the offspring rearing capacity of parents, Proc. R. Soc. Lond. B, 265: $1731-1735$.

Moreno, J. - 1998. The determination of seasonal declines in breeding success in seabirds. Etología, 6: 17-31.

Oro, D. and A. Martínez-Vilalta. - 1994. Factors affecting kleptoparasitism and predation rates upon a colony of Audouin's gull (Larus audouinii) by yellow-legged gull (Larus cachinnans) in Spain, Colon. Waterbirds, 17: 35-41.

Oro, D. - 1995. The influence of commercial fisheries in daily activity of Audouin's gull Larus audouinii in the Ebro Delta, NE Spain, Ornis Fennica, 72: 154-158.

Oro, D., M. Bosch and X. Ruiz. - 1995. Effects of a trawler moratorium on the breeding success of the yellow-legged gull Larus cachinnans, Ibis, 137: 547-549.

Oro, D., X. Genovart, X. Ruiz, J. Jiménez and J. García-Gans. 1996a. Differences in diet, population size and reproductive performance between two close colonies of Audouin's gull Larus audouinii affected by a trawler moratorium, J. Avian Biol., 27: 245-251. 
Oro, D., L. Jover and X. Ruiz. - 1996b. Influence of trawling activity on the breeding ecology of a threatened seabird, Audouin's gull Larus audouinii, Mar. Ecol. Progr. Ser., 139: 19-29.

Oro, D. and X. Ruiz. - 1997. Exploitation of trawler discards by breeding seabirds in the north-western Mediterranean: differences between the Ebro Delta and the Balearic Islands areas, ICES J. Mar. Sci., 54: 695-707.

Oro, D., X. Ruiz, L. Jover, V. Pedrocchi and J. González-Solís. 1997. Diet and adult time budgets on Audouin's gull Larus audouinii in response to changes in commercial fisheries, Ibis, 139: 631-637.

Parsons, K.C. - 1982. Nest-site habitat and hatching success of gulls, Colon. Waterbirds, 5: 131-138.

Parsons, K.C. and J. Chao. - 1983. Nest cover and chick survival in Herring gulls (Larus argentatus), Colon. Waterbirds, 6: 154-159.

Recorbet, B. and G. Bonaccorsi. - 1996. Conception et expérimentation d'abris artificiels pour poussins de goélands d'Audouin
Larus audouinii, Alauda, 64(3): 333-338.

Ruiz, X., L. Jover, D. Oro, J. González-Solís, V. Pedrocchi, V. Roca, M. Genovart, J. C. Abella, J. S. Aguilar and M. Lafuente. - 1996. Ecología y dinámica de la población de la gaviota de Audouin (Larus audouinii). Memoria final. Unpubl. report, ICONA-Universitat de Barcelona. Barcelona.

Ruiz, X., L. Jover and J. Prieto. - 2000. Programa de conservación de la gaviota de Audouin (Larus audouinii). Memoria final. Unpubl. report, OAPN-Universitat de Barcelona. Barcelona.

Varela, J. and E. de Juana. - 1986. The Larus cachinnans michahellis colony of Chafarinas Islands, NATO ASI (Adv. Sci. Inst.) Ser. $\mathrm{G} \mathrm{N}^{\circ} 12$, pp. 231-244.

Wendeln, H. - 1997. Body mass of female common terns (Sterna hirundo) during courtship: relationships to male quality, egg mass, diet, laying date and age, Colon. Waterbirds, 20: 235- 243.

Witt, H., Crespo, J., de Juana, E. and J. Varela. - 1981. Comparative feeding ecology of Audouin's gull Larus audouinii and Herring gull L.argentatus in the Mediterranean, Ibis, 123: 519- 526. 